Document downloaded from:

http://hdl.handle.net/10251/69619

This paper must be cited as:

Ortega-Colomer, FJ. (2013). The evolution of the local role(s) of the university in a low-tech region. International Journal of Technology Management. 12(1):71-87. doi:10.1386/tmsd.12.1.71_1.

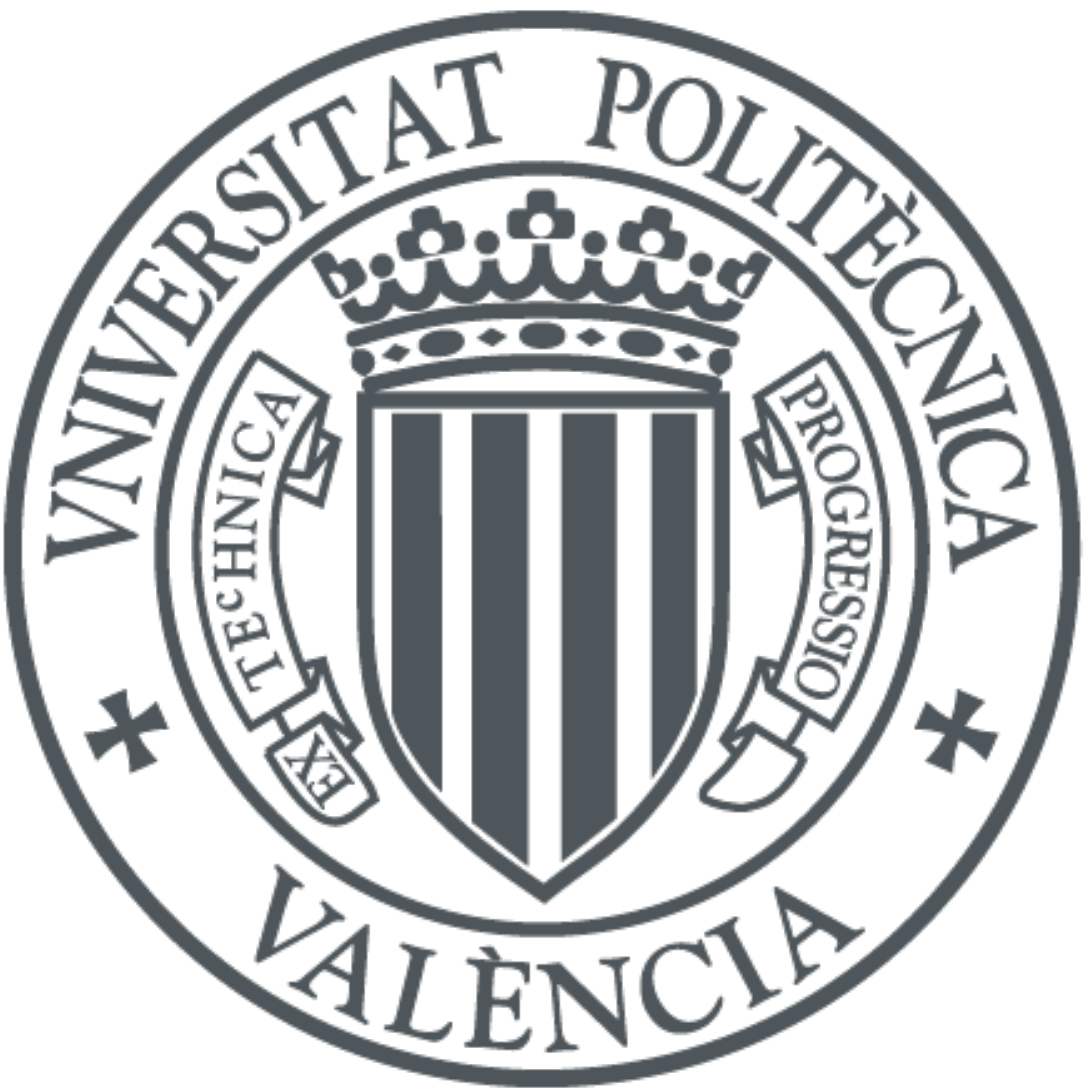

The final publication is available at

http://dx.doi.org/10.1386/tmsd.12.1.71_1

Copyright Inderscience

Additional Information 


\title{
The evolution of the local role(s) of the university in a low- tech region
}

Francisco Javier Ortega-Colomer INGENIO (CSIC-UPV), Universitat Politècnica de València, Caminode Vera s/n, 46022 Valencia, España

\begin{abstract}
The present case study addresses the case of a geographical area neglected by most of the literature about the changing role of Higher Education Institutions (HEIs): the lowtech contexts. This literature has traditionally exhibited two primary aspects. First, a focus on success stories such as entrepreneurial universities located in high-tech regions (e.g. Silicon Valley). Second, it reveals an inclination towards an evolution from ivory towers to entrepreneurial universities. The article argues that this oversimplification does not apply exactly to some environments where the HEIs have maintained links with industry since their inception. The purpose is to demonstrate HEIs' relevance in low-tech contexts with a pre-eminence of small and medium enterprises by taking a historical and qualitative perspective.
\end{abstract}

\section{Keywords}

university-society interaction

innovation systems

historical perspective

qualitative approach 


\section{Introduction}

One underrepresented question in the analysis of agglomeration-based models (industrial districts and clusters) has to do with the role that HEIs have played in different time periods and in specific local contexts. In contrast, this question has recently been addressed using the innovation systems approach in its different forms: local, regional, national and sectoral (Lester and Sotarauta 2007). The focus of attention of the present article will thus be the study of an HEI's role, using concepts and questions from the local systems of innovation approach (La Mothe and Paquet 1998). A possible explanation of why few studies have addressed in detail the role of universities within studies of industrial districts (Becattini 1992; Becattini, Bellandi and Propis 2009) and clusters (Porter 1990; Porter 1998) is that these two approaches have only partially referred to the importance of knowledge generation and dissemination. For that reason, the local innovation systems approach would help to achieve this task, since some attempts have been made in that sense (Acs 2000; Lester and Sotarauta 2007; Plechero 2007). In this vein, and since the local innovation systems approach has stressed knowledge as a crucial factor to include alongside the classical production factors (land, capital and labour), this perspective can more easily accommodate our object of study: the evolution of an HEI’s local role.

To date, in a complementary manner to the above, few studies have been conducted that have minutely analysed the evolution of the local role of HEIs within a context characterized by a high concentration of traditional industries from a historical perspective. The present article will attempt to fill this gap by answering two main 
questions: (1) how has the role of an HEI evolved in a low-tech context, including changes in its interactions with society at different levels (local, regional, national, international)? And (2) how have HEI personnel identified the local needs of new knowledge over the last 30 years (to improve their performance)?

To address these two questions, the integration of two different study fields is required: on the one hand, the analysis of the changing role of the HEIs (Martin 2003), and on the other, the study of the dynamics of knowledge generation and dissemination within specific local contexts (La Mothe and Paquet 1998). Empirically, the study is focused on institutional and academic-level analysis, adopting a bottom-up perspective from the university individuals to the system level. For instance, while most of the studies assume that all the actors located in a region are relevant to the system, the author only concentrates on those who actually are (or have ever been) related with the university, according to the extracted information from university members' stories. This way it is possible to analyse the evolution of the types of mechanisms that have contributed to the development of different (actual) actors at different levels from an innovation viewpoint. Moreover, a study of their historical contribution will shed light on the problems and dilemmas that have been overcome not only from the institutional level but also from the academic level.

\section{Approach}

According to Yin, building case studies through qualitative analysis is fundamental to obtaining a whole perspective of the phenomena and to comprehending the relations between the phenomena and the context (Yin 1994). The empirical analysis has been 
based on the assessment of the qualitative aspects to build case histories by collecting stakeholders' opinions and narratives, by analysing institutional documents and other related studies about the HEI under consideration and its context (Coller 2005). Our case study has included different data collection techniques (i.e. interviews, document analysis and observation, among others), by focusing on a particular HEI from a historical perspective, analysing its evolution in terms of the internal and the external changes, in a context characterized by the dominance of traditional industries (GolfLaville and Ortega-Colomer 2012). The levels of analysis are the following:

- Institutional level (university managers): the author asked nine university managers about the principal shifts in terms of university governance, new roles in management, etc. This analysis has allowed the author to identify the principal periods of the HEI's historical evolution, which is a relevant contribution of the research.

- Academic level (academics): the main incentives and motivations - and the way they have changed over time - were analysed, in addition to the activities undertaken by the academics. These activities were differentiated between academic activities (teaching and research) and extra-academic activities (relationships with their socio-economic environment). After the analysis, the future lines of action of the HEI under study were drawn by asking these academics about their perceptions of their confirmed and potential contribution. Within this category, we interviewed nine academics from different disciplines, such as business administration (two people), textile and paper engineering 
(two people), telecommunications engineering (one person) and mechanical engineering (four people).

\section{The evolution of HEIs' local role: Empirical insights}

This article aims to show the development of a particular type of HEI with more limited aspirations than the world-class universities typically analysed in the literature (Etzkowitz, Webster and Healey 1998: Etzkowitz and Leydesdorff 1999; Etzkowitz et al. 2000). It is not located in an area with abundant high-tech companies. It does not enjoy a huge endowment. Its departments are not packed with world-class academics with access to cutting-edge facilities. Nevertheless, this HEI has been an institution that, in parallel with its European counterparts, has been playing numerous roles throughout its more than one hundred years of history (Blanes-Nadal 1999). That is why such an evolution should be well-documented in order to have new analytical tools to facilitate the adaptation of educational and local development policies to regionally-based institutions and needs.

Achieving this aim entails mapping out what a local innovation system has been, and how the university has been positioned within it. The empirical part starts by introducing the reader to the context under consideration; the subsequent three sections delve into the development of the institution's role across three sequential stages: its origins, its transitional period towards a satellite of a broader university, and finally, the last fifteen years are discussed. Additionally, the perceptions of the university members on the future of the university are further reflected in the last subsection of the empirical part of the article. 


\subsection{Local context}

Our focus of analysis is on the town of Alcoy, and in turn, on the Valencian Central Districts (VCDs, hereafter) which surround it. Over the nineteenth century, a process of industrialization took place in Alcoy (Aracil and García-Bonafé 1974). Its origin is often attributed to numerous factors (Gabinete Sigma 1974). First, while the municipality encompassed 13,000 hectares, opportunities for growth were limited as only two-thirds of these could be cultivated. Second, the area's bountiful sources of water allowed not only for the exploitation of the limited arable land, but also power generation and, subsequently, the installation of the first factories. Third, a very cheap and abundant labour force was readily available from the surrounding countryside to carry out the operational tasks of the production process. A final relevant, though critical sense, factor in the emergence of industry in Alcoy can be attributed to some wealthy landed families from the outlying rural areas who invested their capital in the city with the aim of diversifying their holdings.

As in most places where the Industrial Revolution took root early on, the textile industry is the oldest in the area. Additionally, the utilization of mills for other ends, such as paper manufacturing, was also witnessed early on (at the end of the eighteenth century). This process of innovation lay in diversifying the use of mills beyond textile manufacture. In Alcoy, a priest, who was additionally an industrialist, implemented mills for the paper industry, which then provided packing material for the textile products (Gabinete Sigma 1974). It was precisely these two industries (textile and paper) that propelled others: metallurgy, for example, thrived due to the continuing 
need for repairs to the machinery dedicated to textile and paper manufacturing. Essentially, these three sectors represented the principal engines of local economic development until almost the present day. In addition, many small family-owned shops and workshops made up the rest of the economic landscape.

In terms of economic structure, the most representative sectors in the area today are: textile, toys, plastics, metallurgy, glass-making, food products, chemicals, machine manufacturing, and electronic and electrical equipment and components. Nevertheless, more important than the aforementioned industries is the service sector, comprised of information technology, industrial design, small-scale commerce, banking, healthcare, and other professional branches (SABI 2012). All of the latter emerging sectors have been possible due mainly to the presence of highly-talented technicians coming from the Alcoy HEI and other universities. While these highly-skilled people were creating new firms, the existing industries started to diversify their activities, principally towards the building sector. It should be noted that the present economic structure is the product of an evolution over the past three decades. Over this period of time the aforementioned building sector experienced a dramatic boom, which continued until the global economic crisis of 2008. This growth was due not only to the building sector as such, but also to the related sectors that supported it, both downstream and upstream (namely, banking and real estate). 


\subsection{Alcoy HEI’s local role until its integration with the Universitat Politècnica de}

\section{València}

Following the local innovation systems approach, the author starts by considering institutions that have historically supported the local economy, highlighting specifically the role of educational institutions. To this end, a summary of the official names of local HEIs, their objectives, activities, scope and funding system is provided (see Table 1). The complex legislation over the period of analysis (1828-1970) will be briefly presented. All the information has been extracted from the research of a group of local historians (Aracil and García-Bonafé 1974; Gabinete Sigma 1974; Blanes-Nadal, Garrigós-Oltra and Sebastià-Alcaraz 1997; Blanes-Nadal 1999).

Throughout the nineteenth century, an expansion of the industrial sector (mainly the textile industry) took place in Alcoy, in parallel with other European industrial cities. However, given the absence of a particular state funding system for industrial education the local industrialists of Alcoy initiated a set of negotiations with the local and central government in order to create a technical HEI, and thereby allay their fear of losing their position vis-à-vis their domestic and foreign competitors. Indeed, the Real Fábrica de Paños de Alcoy was the institution responsible for the establishment of the Establecimiento Científico-Artístico (ECA, herafter) in 1828. However, it was not until the start of the twentieth century that education funding was assumed by the state, as other European countries had, hence relieving (somewhat) local governments and business associations of their economic onus.

Since the creation of the first technical educational institution in 1828 until the 1970s, two higher education institutions have predominated the Alcoy sphere of 
education. On the one hand, the Escuela de Peritos (and later Ingenieros) Industriales, which is considered the forerunner of the current Campus of Alcoy - Universitat Politècnica de València, and on the other, the Escuela de Artes y Oficios, devoted since the late nineteenth century to providing a practical education and focused on workshopbased positions, such as graphic designer, illustrator and lathe operator. Apart from these educational institutions, several training colleges also offered specific technical education to factory employees. Table 1 summarizes the chief milestones in the history of Alcoy’s HEIs: their respective evolution can be perceived in each period, as many employed different names for the same local HEIs, concomitant with their changing degrees, funding and scope.

Table 1 The official HEIs in Alcoy

\begin{tabular}{|c|c|c|c|c|}
\hline Period & Name of Centre & $\begin{array}{l}\text { Degree Offered } \\
\text { (around } 3 \text { years) }\end{array}$ & $\begin{array}{l}\text { Funding } \\
\text { Source }\end{array}$ & Scope \\
\hline 1828- & Establecimiento & & Local, & Local \\
\hline \multirow[t]{2}{*}{1853} & Científico-Artístico & & Government & \\
\hline & & & $\begin{array}{l}\text { and private } \\
\text { funds }\end{array}$ & \\
\hline 1853- & Escuela Industrial & Industrial Expert & Local, & Local and \\
\hline \multirow[t]{3}{*}{1901} & Elemental de Alcoy & (Perito Industrial) & Government & National - \\
\hline & & & and private & from 1877 \\
\hline & & & funds & to 1901 , due \\
\hline
\end{tabular}


to the

existence of

only one

HEI with

these

features

1886 In parallel to the Industrial Expert Local, Local and existence of the (Perito Industrial) Government National Escuela Industrial, and private from 1877 the School of Arts funds to 1901, due and Crafts of Alcoy to the is established in existence of 1886 only one HEI with these features

1901- Escuela Elemental EEIA: Technical Local, Local 1907 de Industrias de (lower than Experts) Government Alcoy + Escuela Superior de ESIA: Mechanical, Industrias de Alcoy Chemistry and Electrical Expert. In 
1902, Textile

Expert, and in 1907,

Quantity Surveyor

1907- Escuela de Industrias

1928 de Alcoy (merger of

the two previous

schools)

1928- Escuela Elemental

1942 del Trabajo de Alcoy

$+$

Escuela Superior del

Trabajo de Alcoy
National,

Local

Government

State

Local

1942- Escuela de Peritos Mechanical Expert, State Local

1964 Industriales de Electrical Expert,
Alcoy
Chemistry Expert

and Textile Expert
1964- Escuela
de Engineer
National (and Regional
1994 Ingeniería Técnica
also Regional)
Industrial de Alcoy
Disciplines:
Governmental
(in 1972, this school
Mechanics, Textile,
Bodies
is integrated within
Chemistry, 
the Universitat Electrical and

Politècnica de Electronics

València)

In

1992,

Telecommunications

Source: Own elaboration from Blanes-Nadal (1999) and personal interviews.

The first industrial-era HEI in Alcoy, the ECA, deserves particular consideration as its origins are closely connected to the industrial reality of that moment: some of their founders belonged to the main industrial families of the town. They were convinced of the importance of giving workers a technical education to better anticipate technological change in the industry. The initiative of founding the ECA came in 1828 through the financial support of both the Real Fábrica de Paños de Alcoy and the local government. Until that year, RFPA was the main textile provider of the monarchy, but over time it shifted its role in order to become an employers association, defending the interests of the local textile industry. The objective of the ECA was primarily 'to train technicians who, after a theoretical and practical preparation, were able to competently manage the different sections of a modern mechanized weaving factory’ (Blanes-Nadal, GarrigósOltra and Sebastià-Alcaraz 1997: 7, my translation). Teachers were also supported to firm-based knowledge demands, particularly in two fields: chemistry and mechanics. For instance, they disseminated the latest technical knowledge and techniques through their teaching, in parallel with the introduction of updated bibliographies on their subjects. In fact, the first two privately-funded Cátedras (Chairs) were in these two 
disciplines: Mathematics and Applied Chemistry. Their creation was possible thanks to a renowned industrialist's inheritance. Additionally, to meet the increasing energy demands of factories beyond water-driven machinery, one of the most important challenges faced by faculty members of this new HEI was to seek out mineral deposits in the neighbouring areas, such as coal.

A few years later, in 1853, the Escuela Industrial Elemental was established (Blanes-Nadal 1999), though it did not open until two years later. An additional and critical incentive for founding this educational institution was the prohibitive cost of sending workers to foreign countries (such as France and England) for training. In parallel, there was also an influx of scholars and foreign experts into the area of Alcoy with sufficient knowledge to teach the workers. Industrialists were fearful of losing their competitive position in terms of the quality of their products, so they adopted a proactive - and self-interested - approach by creating a technical school, thereby taking advantage of the increased teaching resources available. It is also important to remark here on the dependence of local firms (mainly textile and paper producers) on machinery providers and chemical products from abroad. The first incorporation of continuous listing paper machinery and jacquard looms took place in the 1880s: this importation vaulted the town of Alcoy to levels of technological competitiveness comparable with the principal Spanish industrial centres of the time. Since then, a critical mass of metallurgy began to emerge, adapting the foreign technology to the local production processes.

In general, the Escuela Industrial Elemental de Alcoy was a small educational institution (in terms of numbers of students and staff) until the decade of the 1980s, when it started to grow considerably. Until then, there were 50 individuals at a time, on 
average, between teachers and students. The latter had to be at least 12 years old when they entered the Escuela. Their attendance was voluntary and there was no limit to the number of years of study. This is understandable, since the student body was comprised not only of young people who had the luxury of dedicating themselves full-time to studies, but also of adults studying in tandem with arduously long workdays and low salaries. For the same reason, the school functioned mostly at night. All of the students believed that, despite their exhaustion after twelve-hour workdays, a better education could offer opportunities for higher-paying jobs within the local area. In fact, the scope of this kind of school was primarily local. Their personnel, in turn, combined their main activity, teaching, with others. For instance, some teachers had their own firms while others were employed in a local production plant. Meanwhile, other teachers were engaged in local government issues. This aspect is noteworthy, since it clearly represents the fluidity of institutional divisions at that time. However, as one of those interviewed noted, an educator's interest in interacting with the industrial environment was a conditio sine qua non for survival: teachers consistently received irregular salary payments and, therefore, were obliged to seek out supplementary income. Moreover, it should be remembered that, despite the economic expansion of Alcoy during those years, poverty remained endemic and the communications limited (roads traversing the surrounding hills were consistently in desperately poor condition). In order to attend to those workers with precarious conditions, the industrialists and the Church jointly created the Círculo Católico de Obreros (1875). A few years later, and defending the same causes, in 1880 a new social organization emerged - La Sociedad Cooperativa El Trabajo - this time composed of non-Catholic workers and devoted to, among other things, assuring them a regular payment in the case of falling ill. 
All the endeavours, carried out mainly by the industrialists, required financial instruments that were largely provided by a local savings bank: Monte de Piedad y Caja de Ahorros de Alcoy, founded in 1875. This organization then merged with other local savings banks, due to the increasing need for capital, and remained until almost the present day the central financial organization for the whole local system. Of course, it was likewise intimately linked to the main actors of the local system: the industrial head managers and the most venerable families who controlled the principal local decisions.

Summarizing, the period from the creation of the first Industrial School (1828) to its integration with the Universitat Politècnica de València (1972) was turbulent - not only for Alcoy, its industry and its HEI, but also for Spain, in general. Despite this, the local systems of innovation was formed by a very solid bourgeoisie that was not only linked to the most important industry at that moment, but was also in charge of many public bodies, such as the local government and the industrial school of engineering, and private bodies, such as the Monte de Piedad y Caja de Ahorros de Alcoy (a local savings bank). Apart from this group, very few people enjoyed a reasonable living standard; a great part of Alcoy's population was living precariously, with few links with the principal local institutions, except the link of the factory worker with his or her employer. In that sense, although the author can affirm that the HEI had fluent relationships with government and also with industry, by looking at the whole local system, it can also be observed a part of the population demanding better working conditions but limited to the periphery of the decision-making processes, controlled mainly by a handful of rich families. On the other hand, there were a group of highlytalented technicians that seems to be the target for the HEI's teaching activities. From the viewpoint of the external forces, the author has also to highlight these influences: 
the international sources for the machinery and chemical products needed in the primary industries of textile and paper. The external actors found in Alcoy a bustling municipality with three different social classes: a firmly-entrenched bourgeoisie, a pool of highly proficient technicians, and an abundant (low-salary) workforce. This latter group did not require the high wages demanded elsewhere in Europe. On the other hand, the HEI personnel were in charge of adapting the external knowledge to the local context conditions.

\subsection{The transition towards a satellite of a broader university}

In 1972, the Universitat Politècnica de València (UPV) underwent a series of changes, among them the adscription of new centres, such as the Industrial School of Alcoy. The UPV thus emerged as an external force triggering a substantial shift in the governance structures of the Alcoy HEI, and bringing new linkages and capabilities to what had been until then a local educational institution. Among the principal changes that affected the university in the years that followed, the 1983 Universities Act is especially remarkable because it allowed the formalization of relationships with the environment through contracts at the institutional level. The way the linkages were established, before the approval of this 1983 Act, was based on contracts at the individual level between professors and industrialists, and not on behalf of the university. These linkages were not allowed until that Act, but surprisingly Spain witnessed not only how the government began to promote a series of practices that had just started to be legal, but also how this type of relationship (mainly formally illegal until then) had curiously been the raison d'être of the existence of the Industrial School of Alcoy. In that sense, 
Alcoy was special in terms of the linkages between industrialists and academics from the Industrial School, now part of a Polytechnic University. As one interviewee affirmed, most of the professors were also businessmen, and thus there existed a fluidity of relationships between university and industry. But the legislative changes also affected the tasks of professors who were required to spend more time on research and less time interacting with society. The interviewee also stated that the most habitual kind of collaborative mechanism, before and after that Act, was based on tailored consultancy projects, such as chemical analysis, or professional advice about adaptations to the production process.

From the viewpoint of context, there was a significant increase in firm creation in previously-existing sectors, and likewise in certain emerging sectors (mainly electronics-based areas and services for small businesses). This allowed a greater range of choice and possibilities for the university to contribute to these emerging industries. Since the 1980s, there was also an increase in the number of students, which involved an increase in both faculty and the emergence of managerial bodies.

In addition to their traditional teaching role and under the influence of several legislative changes regarding higher education, the new teachers' duties incorporated research and service offerings to the professional environment (though the latter was only voluntary). In fact, the reduction of paperwork due to the introduction of supporting staff allowed the faculty to engage in what were for them new activities: they could devote some time to research. Although the previous strong linkages with industry were increasingly fading away, they did not entirely disappear. 
Concomitant with the increase in the number of both teachers and students, one of the most important changes regarding the university organization was the creation of Departments. Departments internally structured and shaped the university in different knowledge domains, among which highlight the Department of Textile and Paper Engineering. Yet, in Alcoy’s industrial school the creation of the departments did not mean that they were composed of academics with a Ph.D., but on the contrary, they were primarily formed by technicians (in Spanish, Peritos Industriales). From that period on, the academic staff at Alcoy had to undergo a process of training, curriculum development and promotion aligned with the academic practices in larger universities. Indeed, until 1991, Alcoy did not offer doctorate coursework, or the full 5-year undergraduate degrees that would be normal in most Spanish universities. After 1991 the School of Alcoy added one Ph.D. course in Textile and Paper Engineering. The eponymous department overseeing this degree was indeed the most connected to the industrial environment because of its wide range of services provided to several textile and paper Small and Medium-size Enterprises (SMEs, hereafter). There were still many lecturers who were also businessmen, or at least, persons very close to local businessmen, though that number was decreasing, thereby setting on the figure of the Profesor Asociado. This figure of the Profesor Asociado, within the new organizational structure of the university that started in the decade of the 1980s in Spain, deserves some additional remarks. The Profesor Asociado was mainly conceived as the figure responsible for keeping alive the linkages between the university and the firms located in the area, because only people with a certain experience in the business world could be contracted under that title. On the other hand, the rest of the university personnel was not adequately incentivized to work together with industry beyond their own 
preferences, or put differently, academics engaged with industry projects were only those who personally took such a decision, there not being clear incentives to do so otherwise.

From the funding perspective, the 1983 Universities Act made explicit reference to the independence of academic institutions and the devolution in terms of funding and planning to the Autonomous Regions. In parallel with the regionalization of higher education policies, a new important institution was added to the innovation systems: the technological institute. All the technological institutes were created as sectorial organizations and adopted some of the roles of the earlier Alcoy Industrial School. Two institutes of technology were located in this area: one devoted to the plastic industry (Technological Institute for Toys. AIJU, located in Ibi) and the other focused on the textile industry (Textile Industry Research Association, AITEX, located in Alcoy). As a result, the new figure of the institute of technology broke with the previous institutional hegemony of the industrial school in terms of knowledge exploration, creation, dissemination and application. Yet, this exchange of roles can only be understood under the tailored services to firms' umbrella. While the Industrial School continued to support local industry by training future technicians and offering several consultancy services to SMEs, from the 1980s on, its personnel had to upgrade their academic CV (internal dynamics of academics), and therefore its contribution to the local environment was not as direct as before. On the other hand, technological institutes were directly involved in several projects devoted to upgrading the firms' technological capacities (this had been indeed its explicit mission since its creation in the mid-1980s). Moreover, the composition of these new organizations was similar to the earlier industrial school. Their partners were the same industrialists, as well as different 
manager associations grouped around a specific sector: for instance, AITEX was formed by several textile firms and its sectorial managers association. For that reason, they started to work together with the technological institute, while the Alcoy's HEI concentrated its efforts on building new kinds of relationships with the academic world. Some years later, around 1995, the Alcoy’s HEI began to reinitiate formal relationships with the local industry. Meanwhile, for almost an entire decade the technological institute had been confirmed as the main partner of the textile firms in the area. In this way, AITEX gained a comparative advantage from the standpoint of building confidence in proposing new research and development projects and innovation projects in tandem with its industrial partners. Despite the increasing separation between the roles of both institutions - the Alcoy's HEI and the technology institute - there was still some collaboration between them. For example, in terms of providing expertise, university personnel were teaching some specific courses which were offered by the institute of technology, above all during the late 1980s and throughout the 1990s. Yet, this connection was gradually weakening over time. Moreover, the cognitive distance between the education level of firms (and thus its new technological partner, AITEX) and the university was enlarged, and this phenomenon did not occur in the relationship between the institute of technology and local firms. In the latter there was no Ph.D.level employee until the beginning of the twenty-first century.

In summary, considering the period from 1970 to 1995 is vital to understanding the current situation of the local innovation systems in Alcoy for several reasons. First, within this period a process of democratization took place not only at the university level (first democratic elections), but also at the societal level (the dictatorial regime ended in Spain). Moreover, this process of democratization led to a massive access to 
education at all levels and thus, an increasing number of students and teachers were engaged in university life. Second, an appearance of new actors, such as the institutes of technology, was witnessed, which in the case of Alcoy were supporting industry in a more direct way, while the university was involved in a project of promotion and academic curriculum development with regard to its personnel (who were increasingly involved in doing research). Third, and much linked to the latter observation, the Alcoy’s HEI was preparing a process of professionalization of its relationships with its environment through the creation of a new figure who would concentrate its contacts, after seeing its separation from the industrial environment and the promotion of new industrial policies that incentivized university-industry linkages. Although during the first years, in the case of Alcoy, this role was assumed by only one person, a team of professionals was gradually formed. Fourth, the identification of local demand for knowledge was mainly assumed by the technological institute not only because the university personnel started to be engaged in several research projects beyond the local level, but also due to the fact that the technological institute generated a continuous source of tailored-services demand in terms of consultancy and other kinds of technological projects: precisely as had occurred earlier with the nascent Industrial School.

\subsection{The local role of the Campus of Alcoy within its local systems of innovation}

The second half of the 1990s decade is considered a vital milestone within the history of the Alcoy's HEI because, for the first time, 5-year studies were introduced within the university programme: Industrial Organization Engineering and the Master of Arts in 
Business Administration. To access the former, students had to finish studies in technical engineering (3 years), and then they had to be enrolled in Industrial Organization (2 years). Moreover, the school started to formalize its relationship with industry in a more visible way.

One of the most far-reaching shifts at all levels was the introduction of Information and Communication Technologies (ICTs) in the university’s everyday life. ICTs allowed Alcoy to redefine numerous subjects and even to create new educational offerings, such as telecommunications and computer engineering. While the former was introduced in 1992 in Alcoy University, the latter was incorporated in 1996.

In 1995, the Área de Relaciones con el Entornowas created in order to enhance and improve the university's contacts with industry. Its rationale came from the thinking that the Alcoy University had traditionally been 'closed to the whole society, since it was serving only a few families' (personal communication). Within this new structure a set of services was established and offered to society in order to facilitate or regulate those university-society linkages in a formal way. First, from the student viewpoint, it was possible to put several job positions (offer side) in contact with students (demand side), which until that time was managed in an informal way by teachers or by industrialists. After a period of experimentation, these job-placement services were improved and are nowadays better managed and benefit both sides: the manager can gain expertise from a high-skilled worker and the student can initiate a legal and compensated relationship within a firm, or with other kinds of organizations: technology institutes, managers associations, foundations, among others. This is the socalled Practicum, which had been working for years in other contexts, even in the current case of Alcoy, but in an informal way. Yet, the possibility of undertaking the 
final dissertation (required before a diploma is granted), through placement in these organizations has been one of the most successful ways to start collaborative projects between the university and its environment. Indeed, this linking mechanism is considered to be one of the most successful with regard to university-society collaborations since its formalization in 1995.

The overall explicit mission of the Universitat Politècnica de València (and also Alcoy University’s mission) since 2007 has been:

to provide its students with an integral education through the creation, development, transfer and critical reflection on science, art and culture, whilst being respectful with ethical principles; an education decidedly leading towards aiding our students in finding an appropriate job in accordance with their studies. (UPV 2011)

However, once the university aims to help its students to find an appropriate job the problem lies in how to achieve this objective. One way is to develop a project where a student is able to implement the theoretical knowledge learnt throughout her university studies. This activity has been considered relevant since students can apply part of the skills acquired at the university, while the host organization can explore new areas by implementing new approaches coming from the university’s expertise (e.g. an engineer candidate), via the intercession of a university teacher as supervisor. Yet, the culmination of the project should not be considered the end of that relationship between the university, student and host organization, but rather the starting point. On the one hand, the student could find a job in the same host organization that helped her to implement the idea for her final thesis. From the host organization perspective, new 
areas could be explored and exploited thanks to the chance taken by the university student and her supervisor. And finally, from the standpoint of the university professor, participation in the project could be the starting point to carrying out new projects with the firm, as a trusting relationship has been established with the former partners. Unfortunately, the explicit incentives of the UPV have not been focused on establishing linkages with the local environment, and only those with a proactive attitude to do so have been part of this group (a minority). Among them the author highlights most of the Profesores Asociados and other professors with previous connections with local firms.

The possibilities for collaborations similar to that mentioned above have increased, but interviewees have stressed the problems generated by the disconnection between the university's offerings and the actual needs of firms located in the area. This issue is germane to one of the topics within the innovation systems approach: the disarticulation of the system provoked by the different actor dynamics in the search for and implementation of innovation projects. The university has tried to tackle this problem by organizing several seminars to (1) serve as an open space to debate and (2) communicate the existing and new educational and research offerings. Regardless, the university has also extended its scope and has sought out partners in research endeavours or other kinds of collaborative projects beyond its traditional typical sphere: Alcoy and its influence area, the VCDs.

\subsection{Perceptions on the future of the university}

The final part of every interview during the research process was devoted to leaving room for the interviewees to express their perceptions in an open manner about the 
future of the university on two levels: the institutional level and the local context level. Here, two types of discourse were identified: one an institutional discourse, more normative, provided by the managerial bodies of the university (directors, university managers and administrative staff), and another provided by academics’ perceptions, obviously more subjective and critical.

An example of these different voices can come from the perceived reality of the current university role. This role is shaped by several reforms, not only at national level as a consequence of the political shift in the national government (towards the right side), but also supranational, exemplified by the well-known Bologna Process. From the national-level viewpoint, while academics highlighted the cuts in education and research budgets - both regionally and nationally - from which they consequently derived increasing pressure in terms of their teaching and research duties but with a minor endowment in this sense, staff coming from managerial bodies did not express any critical comment on such changes that affected university staff, and shared the same rhetoric that expresses the benefits of the university reforms. Apart from this, at the supranational level, academics also felt changes were proposed - and have already started to be implemented - without any process of fluid communication with the affected sector, that is, themselves, the teaching staff. That feeling was expressed as problematic, since university teachers were asked to change their studies plan and the way they conduct their courses, but without any economic and technical support to do so. In that sense, the process is far from solving some of the problems that universities are actually facing, since actions are delinked from reality. On the contrary, the managerial bodies did not express any critical comment on such changes that affected university staff, and shared the same rhetoric that expresses the benefits of the 
university reforms, in terms of European recognition of degrees, flexibility of studies plans, more practice-oriented lessons in classrooms, etc. The following fragment extracted from an interview with an academic can corroborate such a tension between the institutional discourse and the academic perception, exemplified by the implementation of the Bologna Process at Alcoy University:

I'm not really well-informed about the Bologna Process but as far as I know it seems a foolish to me. This process has been collapse all universities in the last four or five years. Everyone is so amaze waiting where and how it takes shape. And hence you feel like you've lost some wonderful years.. After all, the way of teaching that it is promulgated [by the Bologna Process], being honest, I do not believe in it. Why? Because on the one hand it is recommended to have very small groups to make it an extremely personalised teaching and being close to the students and so on, which seems great to me, because as I have said when I studied here [at Alcoy Industrial School] we were few people in class and it was wonderful. But what is the problem? The problem is that although reduced groups at class are encouraged, in terms of efficiency there is a limitation of which each degree must have 50 or 75 students. Then you see that neither politicians nor senior officials, that are promoting such policy recommendations, are able to understand what they have enacted. What good are these changes? Or it may sense, how am I going to personally supervise a class of 50 guys? There are not enough hours in the day! Do you know what I mean? Then it makes no sense, they are doing it very wrong. The original idea might be fine, but you have exhausted. I've been visiting universities in Finland and there were classes of five students and no one was scared. On the contrary,in Spain some universities are deleting degrees with more than one hundred and fifty years of tradition [refering to textile engineering studies] [...]. Everything is a fallacy our politicians do not really know what they are doingpoliticians (Alcoy 20 May 2010 interview). 
That kind of opinion is common in the vast majority of public universities in Spain, where teachers are being pushed to teach more and more (with decreasing resources), which in turn reduces the time they can devote to research or to engaging in projects in collaboration with other actors of local systems of innovation. The only hope academics interviewed have is related to their professional ethics and commitment to their profession, beyond the institutional and legislative changes on all levels. Moreover, some interviewees recognized that, ultimately, the mechanisms used to engage with firms are definitely personablepersonal-like. Additionally, from the vast amount of contacts that academics make in one year, for instance, only a few of them are taking into account and accomplishing their official duties (teaching and research), which coincides with the limit they have. Thus, the so-called third mission of universities, in terms of university-society linkages, is in no way mandatory and relies on the will of each faculty member, who will usually prefer to work with firms or organizations that share a similar culture to them. Here, it is remarkable to highlight how academics perceive the local culture, since most of them (of those interviewed) believed that only very few firms were able to work in collaboration with them, given their respective needs and intellectual aspirations, which in turn could be treated as an evolutionary process of mutual learning. The following testimony of an academic illustrates the latter argument:

The relationship between firms, managers and academics must be reciprocal. In my case, I acknowledge there are firms with which I would never work with. Why? Because, they do not know even what they want. Sometimes they are only thinking about their own problems and there is no collaborative spirit. And sometimes, they do not even think about paying you for your services, and things like that. In the end, it is a matter of evolution. You can be immersed in the 
supervision of some specific projects that you undertake in firm X. Things are going well and from that point on you start a relationship, and moreover, you are recommended and later you are called to visit another firm: 'Hey, come to visit our firm!' (Alcoy 20 May 2010 interview)

Such an evolutionary process can also derive from the creation of a firm in which the academic takes part and makes decisions. The problem lies, as two of the interviewees declared, in that the process of firm creation has to escape university bureaucracy, because otherwise you would find several obstacles that you would not find by contacting, for instance, a friend who would own that firm from that moment on. The obstacles interviewees remarked upon had to do with the complex decision-making schemes and the limitations placed upon the undertaking of certain projects that university spin-offs have to establish. In any case, this kind of mechanism of knowledge

transfer by firm creation was almost nonexistent, apart from two examples found through the interview process, given by two academics. Consequently, the influence of the university on the local industry by this channel seems to be very weak. In contrast, one academic highlighted another type of local engine: the 'residential engine' (extracted from an interview with an academic), referring to the effect that foreign students have on the local economy by renting houses, buying clothes and living in the city.

\section{Conclusion}

This article aimed to show how a specific HEI has played an essential role in a low-tech context, and under which conditions it has operated. With over a century of acquired 
experiences, it can be concluded that its local role has adopted diverse forms in accordance with internal and external circumstances, thereby establishing clearly three principal stages. The first period, stretching from its inception (nineteenth century) to its affiliation with the UPV, was characterized by a centralized form of interaction with certain groups of society, given the case that the well-organized middle class coincided mostly with the two other spheres: local government and industry. In this way, and from the local innovation systems approach, a very articulated system of actors was found and also a fluidity of divisions between them. But the author also observed a wide swath of society that most of the time was not part of the decision-making process: blue-collar workers. Thus, political and legal factors, many of them external, shaped this local group of actors and pulled them in different directions, thus weakening the links between the school and its local environment. Alcoy’s Industrial School had been historically characterized by fluid interactions between academia and industry, but from the 1980s a process of professionalization of its academic personnel brought an increasing separation between academic activity and local industrial needs. Other organizations, such as the institutes of technology, came to cover this gap, while the academic staff did not feel adequately incentivized to undertake collaborative projects with industry. Accordingly, the HEI remained apparently passive in fulfilling the local needs of industry. Despite this, the Industrial School was not totally isolated with respect to its local context, since part of its personnel continued to work together with industry - Profesores Asociados - on their own, or in an informal manner. Apart from this, the author can also conclude that this process of becoming part of a bigger (worldclass) university brought better conditions to face several challenges such as the ICTs revolution, that is, the diversification of the local existing industry or the introduction of 
research findings into traditional industries, as may be applied to the textile industry. An image of a palm tree could better represent the strategy that the Campus of Alcoy has followed from that first stage: having solid roots in the local milieu and several branches in different places according to the contacts their personnel had built and consolidated. In this way, the author has observed the increased participation of university personnel at different levels beyond the local dimension: for example, European Projects or R\&D National Plans. In this sense, the role of contributing actively to local development has been more in the training of highly-skilled and talented people, than in the transference of technology directly to firms, due to the low number of university patents and the inexistent creation of spin-offs. However, certain university personnel have supported their students when they have decided to create a firm, though the entrepreneurial spirit of students has not been found to be exceptional.

Finally, and from a practical viewpoint, this article has attempted to highlight the importance of carrying out historical and context-based analysis when it comes to sketching out the new role of universities in their local innovation systems. Such an ambitious task would require mapping out their capacities and their priorities and not copying or directly importing strategies from elsewhere. It is also important to highlight the enormous complexity in identifying the indicators suited to monitoring their evolution and, at the same time, being able to perform well in certain rankings or scoreboards. For that reason, the author found it more interesting to ask about the university personnel's perception of the evolution of their activities over a long period of time, rather than select a set of indicators isolated from their interpretation. 


\section{References}

Acs, Z. J. (2000), Regional Innovation, Knowledge and Global Change, London: Pinter.

Aracil, R. and García-Bonafé, M. (1974), Industrialització al País Valencià: El cas d'Alcoi, València: Climent, pp. 315.

Becattini, G. (1992), 'El Distrito Industrial Marshalliano como concepto socioeconómico', in F. Pyke, G. Becattini and W. Sengenberger (eds), Los distritos industriales y las pequeñas empresas, I: Distritos industriales y cooperación interempresarial en Italia, Madrid: Ministerio de Trabajo y Seguridad Social, pp. 6179 ,

Becattini, G., Bellandi, M. and De Propis, L. (2009), A Handbook of Industrial Districts, Cheltenham, UK: Edward Elgar.

Blanes-Nadal, G., Garrigós-Oltra, L. and Sebastià-Alcaraz, R. (1997), Antecedents de l'Escola Industrial d'Alcoi: el establecimiento científico artístico de la Real Fábrica de Paños d'Alcoi, Alcoy: Institut d'Estudis Catalans, Societat Catalana d'Història de la Ciència i la Tècnica.

Blanes-Nadal, G. (1999), 'Educación e innovación tecnológica en el proceso de industrialización alcoyana’, Ph.D. thesis, Departamento de Ingeniería Textil y Papelera, Universidad Politécnica de Valencia, Campus de Alcoy.

Coller, X. (2005), Estudio de casos, Colección Cuadernos Metodológicos, núm. 30, Madrid: Centro de Investigaciones Sociológicas, p. 140. 
Etzkowitz, H., Webster, A. and Healey, P. (1998), Capitalizing Knowledge: New Intersections of Industry and Academia, New York: State University of New York Press.

Etzkowitz, H. and Leydesdorff, L. (1999), 'The Future Location of Research and Technology Transfer’, Journal of Technology Transfer, 24: 2-3, pp. 111-23.

Etzkowitz, H., Webster, A., Gebhardt, C. and Terra, B. R. C. (2000), 'The future of the university and the university of the future: Evolution from ivory tower to entrepreneurial paradigm', Research Policy, 29: 2, pp. 313-30.

Gabinete Sigma (1974), La economía de Alcoy y Comarca: Aspectos históricos y estructuras actuales, Valencia: Monte de Piedad y Caja de Ahorros de Alcoy.

Golf-Laville, E. and Ortega-Colomer, F. J. (2012), 'Fuentes de la innovación y el papel de las instituciones en el sistema de innovación textil de un distrito industrial valenciano’, ARBOR, vol. 188- 753, pp. 75-96.

La Mothe, J. de and Paquet, G. (eds) (1998), Local and regional systems of innovation, Amsterdam: Kluwer Academics Publishers.

Lester, R. and Sotarauta, M. (2007), 'Innovation, Universities and the Competitiveness of Regions’, Technology Review, 214, Helsinki: TEKES.

Martin, B. R. (2003), 'The Changing Social Contract for Science and the Evolution of the University', in A. Geuna, A. J. Salter and W. E. Steinmueller (eds), Science and Innovation: Rethinking the Rationales for Funding and Governance, Cheltenham, UK; Northampton, MA: Edward Elgar, pp. 7-29. 
Plechero, M. (2007), 'The Role of Local Universities in Improving Traditional SMEs Innovative Performances: The Veneto Region Case', Master's thesis, Lund: Roskilde University and Lund University.

Porter, M. E. (1990), The Competitive Advantage of Nations: With a New Introduction by the Author, New York, Palgrave.

Porter, M. E. (1998), On Competition, Boston: Harvard Business School Press.

SABI (Sistema de Análisis de Balances Ibéricos) (2012), [CD-ROM], http://sabi.bvdep.com/. Universitat Politècnica de València. Accessed 20 May 2012.

UPV (Universitat Politècnica de València) (2011), 'Strategic Plan of the Universitat Politècnica de València', http://www.upv.es/organizacion/conoce-upv/mision-visionen.html. Accessed 22 March 2012.

Yin, R. K. (1994), Case Study Research, Design and Methods, 2nd edn, Newbury Park, CA: Sage Publications.

\section{Acknowledgements}

The author acknowledges the financial support of the Spanish National R\&D Project (Project ref: SEJ2005-05923/EDUC; and Francisco Javier Ortega Colomer's Grant: BES-2006-13425). The author also feels indebted to Matthew Zugsay for his invaluable help in the revision of the English language of the manuscript. Errors and mistakes are the author's own responsibility. 


\section{Contributor details}

Francisco Javier Ortega-Colomer is Researcher at INGENIO, a joint research institute of the Spanish National Council of Scientific Research ( $\underline{\text { CSIC) }}$ and the Polytechnic University of Valencia (UPV), Valencia, Spain.

Contact: INGENIO (CSIC-UPV), Universitat Politècnica de València, Camino de Vera s/n, 46022 Valencia, Spain.

E-mail: fraorco@ingenio.upv.es

Tel: +34963877048

Fax: +34963 877991 